\title{
EMPATI DAN MOTIF ALTRUISTIK GURU PEMBIMBING DALAM MEMBANTU SISWA MENANGGULANGGI MASALAH SOSIAL DI SMU KODYA PADANG
}

\author{
Oleh : \\ .Firman Firman dan Khairani Khairani \\ Jurusan Bimbingan dan Konseling FIP Univ.Negeri Padang \\ Email : firman@konselor.org
}

\begin{abstract}
Abstrak
Penelitian ini bertujuan mengungkapkan empati dan motif altruistik guru pembimbing dalam membantu siswa menyelesaikan masalah sosial yang dialminya. Subjek penelitian adalah guru pembimbing di SMU Kodya Padang. Pengumpulan data dilakukan dengan menggunakan kuessioner. Selanjutnya data tersebut dianalisis dengan menggunakan prosentase dan analisis regresi umum. Dari analisis data ditemukan sebagian besar guru pembimbing yang bertugas di SMU Kodya Padang berempati dan memiliki motif altruistik dalam membantu siswa menyelesaikan masalah sosial. Motif altruistik guru pembimbing dalam membantu menyelesaikan masalah sosial yang dialami siswa di SMU Kodya Padang dijelaskan oleh empati sebesar 54,3 \%.
\end{abstract}

\section{A. Pendahuluan}

Berbagai masalahan sosial dialami siswa di sekolah ditunjukkan oleh perilaku melanggar aturan, berkelahi serta konflik dengan guru dan teman sesama siswa.

Kehadiran bimbingan dan konseling dengan melibatkan seluruh personil sekolah, semakin diperlukan oleh siswa untuk menanggulanggi permasalahan tersebut. Walaupun demikian secara khusus keberhasilan layanan bimbingan dan konseling ditentukan oleh guru pembimbing.

Depdikbud (1993) menjelaskan tugas pokok guru pembimbing adalah menyusun program, melaksanakan program evaluasi pelaksanaan bimbingan, analisis hasil dan tindak lanjut terhadap peserta didik yang menjadi tanggung jawabnya.

Sebagian guru pembimbing ditemukan tidak sepenuhnya membantu siswa menanggulanggi masalah sosial yang dialaminya. Guru pembimbing kurang tanggap terhadap permasalahan yang sedang dihadapi siswanya. Apabila dikalkulasikan jumlah siswa yang mendapat layanan tidak sesuai dengan target yang diinginkan.

Liebert, (1979:320) mengemukakan faktor penentu kesediaan seseorang memberi pertolongan adalah berempati kepada orang yang membutuhkan. Melalui empati seseorang dapat mentransformasikan penderitaan orang lain menjadi ketidak nyamanan 
pada diri sendiri, sehingga bertanggung jawab atas keadaan yang tidak menyenangkan orang lain tersebut.

Bantuan yang diberikan oleh guru pembimbing kepada siswa yang mengalami masalah sosial, seharusnya didasari oleh panggilan hati nuraninya dan ikut merasakan apa yang sedang dirasakan siswa tersebut. Kemampuan berempati merupakan salah satu faktor penentu keberhasilan layanan bimbingan dan konseling.

Prayitno (1987:46) mengemukakan empati pada dasarnya adalah mengerti dan dapat merasakan perasaan orang lain (klien). Empati ini akan lebih lengkap jika diiringgi oleh pengertian dan penerimaan terhadap apa yang dipikirkan oleh orang lain.

Empati tidak dapat dipelajari tetapi dapat dilatihkan melalui pendidikan tertentu. Guru pembimbing sebelum bertugas, telah dilatih berempati dengan memperoleh pengetahuan dan keterampilan yang terkait dengan permasalahan lingkup pekerjaannya. Latihan berempati membantu calon guru pembimbing memahami situasi dengan lebih tepat dan akurat tentang orang lain.

Apabila diamati dalam pelaksanaan Layanan Bimbingan dan Konseling di sekolah, ditemukan tidak semua guru pembimbing bersedia menolong siswa yang sedang mengalami masalah. Pertolongan diberikan terhadap siswa hanya didorong oleh tuntutan yang telah digariskan dalam program layanan bimbingan dan konseling dan bukan didorong oleh keinginan guru pembimbing itu sendiri. Tidak jarang ditemukan guru pembimbing banyak melakukan kegiatan pendukung seperti mengumpulkan data, mengurus absen, mengawasi siswa yang bolos dan terlambat dibandingkan layanan bantuan yang dibutuhkan siswa.

Berdasarkan informasi dari beberapa orang siswa, mengungkapkan guru pembimbing kurang merasakan apa yang sedang dirasakannya, sehingga tidak jarang ditemukan guru pembimbing marah-marah terhadap siswa yang sedang bermasalah. Layanan yang diberikan kepada siswa kurang tuntas dan kadang-kadang tidak sampai kepada penyelesaian masalah yang dibutuhkan siswa.

Bertitik tolak dengan uraian tersebut, terlihat bahwa kemampuan untuk memahami apa yang dirasakan siswa (empati) mempengaruhi dorongan guru pembimbing untuk memberikan pertolongan kepada siswa yang membutuhkannya (motif alturistik). Batson, Clark serta Eisenberg (Santrock,1986:626) menjelaskan 
keadaan yang paling mungkin menimbulkan motif alturitik adalah emosi empatik terhadap orang yang membutuhkan.

Sehubungan dengan hal itu, menarik untuk ditelusuri lebih lanjut melalui penelitian ini bagaimana empati dan motif altruistik guru pembimbing dalam membantu menyelesaikan masalah sosial yang dihadapi siswa SMU Kodya Padang. Penelitian ini bertujuan untuk mengungkapkan empati dan motif altruistik guru pembimbing terhadap siswa yang mengalami masalah sosial.

Pengungkapan empati dan motif altruistik guru pembimbing dalam membantu siswa menanggulanggi masalah sosial bermanfaat untuk pengembangan psikologi dalam praktek bimbingan konseling. Pada gilirannya nanti diharapkan Jurusan Bimbingan dan Konseling dan Departeman Pendidikan Nasional dapat mempersiapkan dan membina guru pembimbing yang bertugas di sekolah-sekolah.

\section{B. Metode Penelitian}

Penelitian ini tergolong ke dalam penelitian deskriptif. Populasi penelitian ini adalah guru pembimbing yang bertugas di SMU Negeri dan Swasta di Kodya Padang, dengan karakteristik sekolah yang mempunyai guru pembimbing berlatar belakang pendidikan S1/D3 Bimbingan dan Konseling, guru mata pelajaran yang telah mengikuti pelatihan Bimbingan dan Konseling pola 180 jam dan guru pembimbing yang SK nya di sekolah yang bersangkutan menimal 2 tahun. Pengambilan sampel menggunakan simple random sampling. Akhirnya diperoleh sampel sebanyak 56 orang.

Data yang diperlukan dalam penelitian ini dikumpulkan melalui angket. Menjawab pertanyaan nomor 1 dan 2 , setelah data dikumpulkan diolah dengan menggunakan proses tabulasi dan hasilnya dipaparkan dalam bentuk prosentase. Di samping itu, menjawab pertanyaan nomor 3, menggunakan analisis regresi umum dengan menggunakan bantuan modus Seri Program Statistik (SPS) dari Sutrisno Hadi dan Seno Pamardiyanto dengan bantuan IBM/PC

\section{Hasil Penelitian dan Pembahasan}

Berdasarkan pengolahan data yang telah dikumpulkan melalui angket, diperoleh keterangan sebanyak 34,29 \% guru pembimbing yang bertugas di SMU Kodya Padang 
sering berempati terhadap permasalahan sosial yang dialami siswa, selanjutnya $30,75 \%$ sering sekali, 20,69\% jarang, 10,26\% jarang sekali, 4,01\% tidak pernah berempati terhadap permasalahan sosial yang dialami siswa di SMU Kodya Padang. Hal ini berarti sebagian besar guru pembimbing yang bertugas di SMU Kodya Padang dapat berempati terhadap permasalahan sosial yang sedang dialami siswa ( 34,29 \% sering, 30,75\% sering sekali, 20,69\% jarang).

Di samping itu, ditemukan sebanyak 35,61\% guru pembimbing yang bertugas di SMU Kodya Padang sering memiliki motif altruistik dalam membantu siswa menyelesaikan masalah sosial yang dilaminya, selanjutnya $34,865 \%$ sering sekali, $17,20 \%$ jarang, 7,325 jarang sekali, serta $5,00 \%$ guru pembimbing yang bertugas di SMU Kodya Padang tidak pernah memiliki motif altruistik dalam membantu siswa menyelesaikan masalah sosial. Hal ini berarti sebagian besar guru pembimbing yang bertugas di SMU Kodya Padang memiliki motif altruistik dalam membantu siswa menyelesaikan masalah sosial ( $35,61 \%$ sering, $34,865 \%$ sering sekali, $17,20 \%$ jarang).

Berdasarkan pengujian melalui analisis regresi atas pengaruh empati terhadap motif altruistik guru pembimbing dalam membantu menyelesaikan masalah sosial yang dialami siswa SMU Kodya Padang, ditemukan F-regresi sebesar 64,229 dengan peluang ralat sebesar 9,351 Hipotesis yang digunakan adalah hipotesis berarah, maka nilai $\mathrm{p}$ dibagi dua sehingga $p$ menjadi 4,6755. Nilai $p=4,6755$ menunjukan adanya pengaruh yang signifikan dari empati terhadap motif altruistik guru pembimbing dalam membantu siswa menyelesaikan masalah sosial di SMU Kodya Padang. Dengan demikian hipotesis alternatif pengaruh empati terhadap motif altruistik guru pembimbing dalam membantu siswa menyelesaikan masalah sosial diterima dan hipotesis nihil terbukti ditolak. Korelasi antara empati dengan motif altruistik dengan empati guru pembimbing dalam menyelesaikan masalah sosial yang dialami siswa, adalah 0.737 , sedangkan koefisien diterminasinya ( $\mathrm{r} 2)$ sebesar 0.543 . Hal ini menunjukan motif altruistik guru pembimbing dalam membantu menyelesaikan masalah sosial yang dialami siswa dijelaskan oleh empati sebesar 54,3\%. Sedangkan sisanya 45,7 \% dijelaskan oleh variabel lain.

D. Pembahasan 
Sebagian besar guru pembimbing di SMU Kodya Padang ditemukan dapat berempati terhadap permasalahan sosial yang dialami siswa. Walaupun demikian apabila dikaji secara mendalam guru pembimbing yang sering sekali berempati sebanyak 30,75 $\%$ dan sering sebanyak $34,19 \%$. Hal ini berarti tidak semua guru pembimbing dapat merasakan dan menempatkan diri berada pada posisi siswa yang sedang mengalami masalah sosial.

Kesulitan guru pembimbing selalu berempati terhadap permasalahan sosial dialami siswa diperkirakan karena sebagian besar guru pembimbing berjenis kelamin perempuan $(84,78 \%$ ) dengan latar belakang pendidikan Sarjana Muda/D3 44,48 \%. Sedangkan komposisi jenis kelamin siswa laki-laki dengan perempuan di SMU Kodya Padang seimbang. Tidak jarang juga permasalahan sosial sebagian besar dialami siswa laki-laki di bandingkan dengan siswa perempuan.

Soelaiman (1992:482-484) menjelaskan individu dapat berempati dengan baik terhadap perasaan orang lain apabila telah mengalami perasaan tersebut. Empati sebagian besar lahir tidak direncanakan pada saat orang menaruh perhatian pada sikorban.

Kemampuan guru pembimbing berempati akan mewarnai motif altruistik yang mereka miliki dalam membantu siswa menanggani masalah sosial. Sesuai dengan uraian terdahulu, guru pembimbing di SMU Kodya Padang ditemukan sebagian besar telah memiliki motif altruistik dalam memberikan pertolongan terhadap siswa yang sedang mengalami masalah sosial. Apabila dikaji secara mendalam tidak semua guru pembimbing selalu memiliki motif altruistik ( $35 \%$ sering dan 34,865 \% selalu). Hal ini berarti tidak semua guru pembimbing di SMU Kodya Padang memiliki dorongan untuk bertindak secara sukarela menolong siswa dengan imbalan perasaan senang, puas setelah melakukan pertolongan.

Kekurangan motif altruistik yang dimiliki guru pembimbing di SMU Kodya Padang diperkirakan karena sebagian besar guru pembimbing perempuan $(84,78 \%)$, sedangkan siswa laki-laki dan perempuan di SMU seimbang. Masalah sosial yang dialami siswa di sekolah tidak jarang dilami siswa kaki-laki yang ditunjukan oleh perilaku perkelahian dan pembunuhan. Tomhson dan Keasey (1985:562) menjelaskan jenis kelamin dan intelegensi mempengaruhi apakah seseorang terdorong membantu orang lain. Bernstein (1994:662) menjelaskan individu cenderung menolong orang yang 
menarik atau disukainya. Pria lebih banyak menolong wanita yang menarik secara fisik dibandingkan dengan yang tidak.

Berdasarkan hasil perhitungan diperoleh keterangan motif altruistik guru pembimbing dalam membantu menyelesaikan masalah sosial yang dialami siswa dijelaskan oleh empati sebesar 54,3\%. Dengan demikian empati berpengaruh terhadap motif altruistik guru pembimbing dalam membantu siswa menyelesaikan masalah sosial. Toi dan Batson (1982) menjelaskan subyek yang ada dalam kondisi empati rendah melakukan sedikit pertolongan dalam kondisi dimana penghindaran mudah dilakukan dari pada jika penghidarannya sulit, tetapi subyek yang berada dalam kondisi empati yang tinggi, menunjukkan jumlah pertolongan yang tinggi, walaupun penghindaran terhadap situasi itu mudah dilakukan.

Batson (1981) menjelaskan bahwa empatik siap menolong, baik penghindaran terhadap situasi mudah atau sulit dilakukan. Bila empatinya rendah, subyek siap menolong, terutama bila penghindaran sulit dilakukan, sehingga motivasi empatik dipandang sebagai motivasi instrinsik. Tanpa melihat apakah penghindaran terhadap adanya orang yang membutuhkan itu sulit atau mudah, orang yang empatik tetap alturitik (Phares, 1984:563-565).

Berdasarkan uraian tersebut terlihat bahwa rasa empati terhadap siswa yang mengalami masalah sosial merupakan motivator penting guru pembimbing untuk menolong. Sebab saat guru pembimbing merasa berempati kepada siswa yang sedang mengalami masalah sosial ada rasa sedih dan derita sementara yang ia rasakan. Kemudian motivasi yang timbul dari empati itu ditunjukkan untuk menghilangkan pederitaan serta akibat yang mungkin dialami siswa.

\section{E. Kesimpulan dan Saran}

\section{Kesimpulan}

1. Sebagian besar guru pembimbing yang bertugas di SMU Kodya Padang berempati terhadap siswa yang mengalami masalah sosial ( $34,29 \%$ sering, 30,75 $\%$ sering sekali, 20,69\% jarang). 
2. Sebagian besar guru pembimbing yang bertugas di SMU Kodya Padang memiliki motif altruistik dalam membantu siswa menyelesaikan masalah sosial ( 35,61 \% sering, 34,865 \% sering sekali, 17,20\% jarang).

3. Terdapat pengaruh yang signifikan antara empati dengan motif altruistik guru pembimbing dalam membantu siswa menyelesaikan masalah sosial di SMU Kodya Padang. Motif altruistik guru pembimbing dalam membantu menyelesaikan masalah sosial yang dialami siswa di SMU Kodya Padang dijelaskan oleh empati sebesar 54,3 \%. Sedangkan sisanya 45,7 \% dijelaskan oleh variabel lain yang tidak diungkapkan melalui penelitian ini. 